Ege Tıp Dergisi / Ege Journal of Medicine 2020; 59 (3): 232-234

\title{
Adneksiyal kitleyi taklit eden ileum kökenli gastrointestinal stromal tümör
} Gastrointestinal stromal tumor of the ileum mimicking adnexal mass

\author{
Issmet Hortu ${ }^{1}$ Gizem Kocaoğlu ${ }^{1}$ (D) Feride Algül ${ }^{1}$ (i) \\ Gürdeniz Serin ${ }^{2}$ Ali Akdemir ${ }^{1}$ (iD \\ ${ }^{1}$ Ege Üniversitesi Tıp Fakültesi Kadın Hastalıkları ve Doğum Anabilim Dalı, İzmir, Türkiye \\ ${ }^{2}$ Ege Üniversitesi Tıp Fakültesi Patoloji Anabilim Dalı, İzmir, Türkiye
}

\section{Öz}

Adneksiyal kitleler genellikle benign yapıda olup kadınlarda her yaş grubunda görülebilen patolojilerdir. Tıbbi özgeçmiş, fizik muayene, tümör belirteçleri ve görüntüleme yöntemleri preoperatif değerlendirme esnasında mutlaka birlikte yapılmalıdır. İnce barsak tümörleri diğer gastrointestinal tümörlerden daha az sıklıkta görülür. Günümüzde yüksek teknolojiye sahip görüntüleme yöntemleri sıkça kullanılıyor olsa da bu tümörler adneksiyal kitlelerle kolayca karışabilmektedir. Bu olgu sunumunda, adneksiyal kitle nedeniyle opere edilen ve gastrointes-tinal stromal tümör (GiST) olduğu ortaya çıkan 60 yaşında bir hasta sunulmuştur.

Anahtar Sözcükler: Adneksiyal kitle, gastrointestinal stromal tümör, ileum.

\begin{abstract}
Adnexal masses are usually benign pathologies that can be seen in women of all ages. Medical history, physical examination, tumor markers and imaging modalities should be performed together in during preoperative evaluation. Benign and malignant tumors of small intestine occur less frequently than other gastrointestinal tumors. Although high-tech imaging techniques are frequently, such neoplasms cannot be easily distinguished with adnexal masses. In this case report, a 60-year-old woman who was operated for adnexal mass and revealed to have gastrointestinal stromal tumor of the ileum was presented.
\end{abstract}

Keywords: Adnexal mass, gastrointestinal stromal tumor, ileum.

\section{Giriş}

Adneksiyal kitleler fonksiyonel, konjenital, inflamatuar ve neoplastik süreçlere bağlı olarak adnekslerde (tuba uterinalar, overler, ligamentum latum uteri) ve bunlara komşu organlarda oluşan kitlelerdir. Adneksiyal kitleler hastaneye başvuru sıklığına göre 4. en sık jinekolojik nedendir. 40 yaş altında insidansı 0,4-8,9/100.000, 60-80 yaş aralığında ise 60/100.000'dir (1). Bu kitlelerin yönetiminde ayırıcı tanı çok önemlidir; yaşa ve orijinine göre patolojiler ve tedavileri büyük farklıııklar gösterir. Medikal özgeçmiş, sistemik fizik muayene, tümör belirteçleri (özellikle CA125) ve görüntüleme yöntemleri preoperatif değerlendirmede birlikte yapılmalıdır (2). Gastrointestinal stromal tümör (GIST) ise primer olarak gastrointestinal sistemden (GIS) kaynaklanan, spesifik histolojik özellikleri olan mezenkimal tümörlerdir. En sık mide kaynaklıdır ve tüm gastrik malignitelerin \%1'ini oluşturur. İkinci sıklıkta ise ince bağırsaklarda görülür (3). Burada adneksiyal kitle ve postmenopozal endometriyal kalınlık artışı saptanması üzerine operasyon kararı alınan, intraoperatif dönemde ince barsak kökenli tümör tespit edilen olgu literatür verileri eşliğinde tartışılmıştır.

\section{Olgu}

Sekiz yıldır postmenopozal dönemde olan 60 yaşında kadın hasta, rutin jinekolojik kontrolleri sırasında adneksiyal kitle saptanarak kliniğimize yönlendirildi. Tıbbi özgeçmişinde hipertansiyon, üç vajinal doğum ve hemoroidektomi öyküsü mevcuttu. 
Tümör belirteçlerinde CA125 (7 U/ml), CA15-3 $(9.9 \mathrm{U} / \mathrm{ml})$, CEA $(1.22 \mathrm{ng} / \mathrm{ml})$ değerlerinin normal; CA19-9:32 U/ml (<27), AFP: $7.17 \mathrm{ng} / \mathrm{ml}(<7)$ değerlerinin ılımlı yüksek olduğunu gördük. Bimanuel vajinal muayenede uterus antevert, normal cesamette; sol adneks normal, sağ adnekste semimobil bir kitle palpe edildi. Transvajinal ultrasonografide endometrium çift duvar kalınlığı 7,7 $\mathrm{mm}$, uterus normal, sol over atrofik, sağ adneksial alanda hipervasküler, 50x40 mm boyutunda, heteroekojen yapıda kitle izlendi. CA 19-9 yüksekliği olduğu için alt-üst GiS endoskopik tarama yapıldı. Endoskopide hiatal yetmezlik ve pangastrit, kolonoskopide hemoroidal hastalık görüldüğü raporlandı. Manyetik rezonans görüntülemede (MRG) ise sağ adneksiyal alanda düzgün sınırlı, homojen kontrast madde tutan, multilobüle 50×40 $\mathrm{mm}$ solid kitle izlendi (Şekil-1a). Hastaya laparotomi planlandı. İntraoperatif batın gözleminde uterus ve bilateral overler atrofik izlendi. İleumdan kaynaklanan yaklaşık $50 \times 40 \mathrm{~mm}$ boyutunda, hiperemik görünümde, vasküler yapıda kitle görülmesi üzerine genel cerrahi ekibi de operasyona dahil oldu (Şekil-1b). Kitle, kaynaklandığı yaklaşık $20 \mathrm{~cm}$ uzunluğundaki mezoileal segment ile birlikte rezeke edildi. Uç uca anastomoz yapıldı. Frozen (donuk kesit) sonucu GIST olarak raporlandı. Postmenopozal endometrial kalınlık artışı saptanmış olması ve hastanın da isteği üzerine total abdominal histerektomi ve bilateral salpingoooferektomi (TAH-BSO) yapıldı. Patoloji incelemesi sonucunda ileumda GIST (tümör muscularis propria içinde gelişmiş, yaklaşık $5,1 \mathrm{~cm}$, ilerleyici hastalık açısından orta risk grubunda), uterusta endometrial polip ve submüköz leiomyom bulunduğu; bilateral adnekslerin ise olağan olduğu bildirildi.

Hasta cerrahi sonrasında tıbbi onkoloji birimine yönlendirildi. Bir yıl süreyle İmatinib tedavisi verildi. Hastadan tıbbi verilerinin yayınlanabileceğine ilişkin yazılı onam belgesi alındı.

\section{Tartışma}

Gastrointestinal stromal tümör, iğsi hücreli, epiteloid ve GiS'in pleomorfik mezenkimal tümörleri olarak interstisyel Cajal hücrelerinden kaynaklanırlar (7) (Şekil-1c, d, e). İmmünohistokimyasal olarak c-KIT (CD117, KIT -protein, stem cell reseptör) ya da CD34 (human progenitor antigen cell) eksprese etmektedirler (9). DOG1, GIST tanısında kullanılan yeni bir gendir (Şekil-1f, g, h).

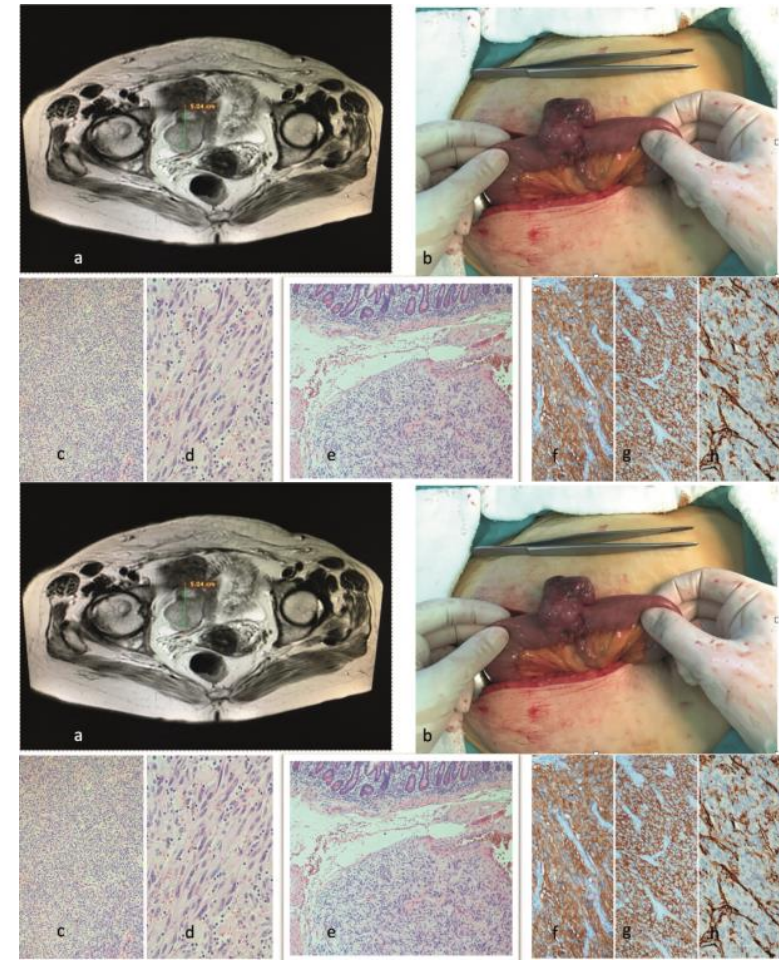

Şekil-1 (a). MRG'de sağ adneksiyal alanda izlenen hiperintens kitle. (b). İleum üzerinde stromal tümör (makroskopik intraoperatif görünüm). (c). Normal barsak mukozası altında lokalize iğ hücreli tümör (100x büyütme, H\&E). (d). Hafif pleomorfizm gösteren iğsi hücre demetleri $100 x$ büyütme, H\&E. (e). Hafif pleomorfizm gösteren iğsi hücre demetleri 400x büyütme, H\&E. (f). İmmunohistokimyasal incelemede (400x) tümör hücrelerinde CD117 ile diffüz sitoplazmik boyanma, (g). İmmunohistokimyasal incelemede (400x) tümör hücrelerinde DOG1 ile diffüz membranöz boyanma, (h). İmmunohistokimyasal incelemede (400x) tümör hücrelerinde CD34 ile negatif boyanma.

Gastrointestinal stromal tümörler tüm gastrointestinal mezenkimal tümörlerinin \%80'ini oluşturmakla beraber en sık \%50-70 kadarı mide kaynaklıdır. \%20-30'u ince bağırsakta, \%10'u kolon ve rektumda, \%5'i özofagusta yerleşir (4). GiST, ince barsağın en sık karşılaşılan mezenkimal tümörüdür ve tüm ince bağırsak tümörlerinin \%15-20'sini oluşturur (4). Olguların çoğu sporadik olmakla beraber c-KIT ve "platelet derived growth faktor receptor- $\alpha$ (PDGFR- $\alpha$ )" mutasyonu görülen ailelerde, Nörofibromatozis Tip1 ve Carney triadı olan hastalarda da sık olarak gözlenmektedir (9). Tüm GiS tümörleri arasında sıklık açısından adenokarsinom ve lenfomadan sonra üçüncü sırada yer alır (8). Bazen multifokal olabilen GisT'lerin boyutu değişken olmakla birlikte 
2 cm'den küçük kitleler malignite açısından düşük risk taşırken, $5 \mathrm{~cm}$ 'den büyük kitleler malignite açısından daha fazla risk taşımaktadırlar. $2 \mathrm{~cm}$ ve daha küçük GIST'ler genellikle asemptomatiktir ve başka bir sebep yüzünden yapılan cerrahi, radyoloji veya endoskopi esnasında tesadüfen tespit edilirler (6). GiST'ler çoğu kez asemptomatiktir. Semptomatik olduğunda ise erken doyma, karında şişlik, gastrointestinal kanama gibi özgün olmayan belirtiler görülür. Prognozun belirlenmesinde tümörün lokalizasyonu, çapı ve mitotik aktivitesi ile optimal operasyon yapılabilirliği kullanılır (8). Tanıda immünohistokimyasal tarama gereklidir; çoğu tümör CD34 (\%70-78) ve CD117 (\%72-94) antijenlerini eksprese ederler. CD117 pozitifliği, tüm histolojik varyant ve anatomik yerleşim gösteren benign ve malign stromal tümörlerde izlenmektedir (9).

Hastamızda CA19-9 ve AFP yüksekliği mevcuttu. CA19-9 genel olarak pankreas kanserinin yanı sıra kolorektal, mide, özofagus ve hepatosellüler kanserlerde; ayrıca kolanjit, kronik karaciğer hastalığı, irritabl barsak sendromunda da yükselmektedir. AFP ise hepatoselüler karsinom, testis kanseri ve over germ hücreli tümörlerinde yüksek bulunmuştur (7). GiST'in temel tedavi yöntemi cerrahi rezeksiyondur. Lenfatik metastaz oranının düşük olması nedeniyle lenfadenektomi önerilmemekte; radyoterapi ile tedavisi çevre organların aşırı hassas olması nedeniyle uygulanmamaktadır (9). Klinik ve patolojik olarak yüksek riskli hastalarda kemoterapi önerilir. GIST tanılı vakalarda tirozin kinaz inhibitörü olan imatinib kullanımıyla \%50-80 vakada remisyon ve regresyon sağlanabilmektedir. İmatinib unrezektabl, nüks veya metastatik GiST tedavisinde ilk seçenektir. Selektif bir tirozin kinaz inhibitörü olan imatinib mesilat, c-KIT proto-onkogen ve trombosit kaynaklı büyüme faktörü-alfa reseptörünü hedefler (10).

\section{Sonuç}

Preoperatif dönemde adneksiyal kitle ve ayırıcı tanılara yönelik tetkikler yapılmış ancak, operasyon ile doğru tanıya ulaşılabilmiştir. Pelvik kitlelere yaklaşım sırasında, ne kadar nadir bulunsalar da GiS tümörlerinin (özellikle ince bağırsak kaynaklı tümörler) ayırıcı tanılar arasında akılda tutulmaları gerekmektedir.

Çıkar çatışması: Yazarlar çıkar çatışması beyan etmemişlerdir.

\section{Kaynaklar}

1. Cancer incidence in Sweden. Annual report 1996. Stockholm: Swedish Cancer Registry, Centre for Epidemiology, National Board of Health and Welfare; 1996.

2. Brown DL, Doubilet PM, Miller FH, et al. Benign and malignant ovarian masses: selection of the most discriminating gray-scale and Doppler sonographic features. Radiology 1998; 208: 103-10.

3. Hirota S, Isozaki K. Pathology of gastrointestinal stromal tumor. Pathol Int 2006; 56: 1-9.

4. Quek R, George S (2009) Gastrointestinal stromal tumor: a clinical overview. Hematol Oncol Clin North Am 23: 69-78.

5. Dolscheid-Pommerich RC, Manekeller S, Walgenbach-Brünagel G, Kalff JC, Hartmann G, Wagner BS, Holdenrieder S. Clinical Performance of CEA, CA19-9, CA15-3, CA125 and AFP in Gastrointestinal Cancer Using LOCI $^{\text {TM }}$-based Assays. Anticancer Res. 2017 Jan; 37 (1): 353-359.

6. Miettinen M, Lasota J. Gastrointestinal stromal tumors: rewiew on morphology, molecular pathology, prognosis and differential diagnosis. Arch Pathol Lab Med 2006; 130: 1466-1478.

7. Dougherty MJ, Compton C, Talbert M, Wood WC. Sarcomas ofthe gastrointestinal tract. Separation into favorable and unfavorable prognostic groups by mitotic count. Ann Surg 1991; 214: 569-574.

8. Oktay Büyükaşık, A.Oğuz Hasdemir, Abuzer Dirican, Cavit Çöl. Gastrointestinal Stromal Tümörler. İnönü Üniversitesi Tıp Fakültesi Dergisi, 16 (4) 227-232 (2009).

9. V Pinto, G Ingravallo, E Cicinelli, A Pintucci, G S Sambati, M Marinaccio, V D'Addario. Gastrointestinal Stromal Tumors Mimicking Gynecological Masses on Ultrasound: A Report of Two Cases. Ultrasound Obstet Gynecol. 2007; 30: 359-61.

10. Levent Akman, Behiye Seda Hurşitoğlu, Rasim Farajov, Mustafa Coşan Terek, Murat Sezak, Deniz Şimşek, Hüseyin Yılmaz. Gastrointestinal stromal tumor and leiomyoma of the ileum mimicking adnexal mass: A report of two cases. Turk J Gastroenterol 2015; 26: 56-59. 